\title{
Implementation Regulated in the Minister of Health Indonesian Republic Number 856/Menkes/ Sk/Ix /2009 about Hospital Emergency Installation in Bendan Pekalongan City Hospital
}

\author{
(Implementasi Kepmenkes RI No. 856/Menkes/Sk/Ix/2009 Tentang Standar Instalasi Gawat
} Darurat (IGD) Rumah Sakit Di RSUD Bendan Kota Pekalongan)

\author{
Anik Indriono, Tjahjono Kuntjoro, Joko Purwoko \\ email: anikindriono@ymail.com
}

Health Law Master Program, Soegijapranata Catholic University of Semarang

\begin{abstract}
Hospitals in Indonesia are part of the health care system. The health services are started from Emergency Installation, which provided emergency service. An emergency is a life-threatening and disabling condition requiring fast, precise, effective and quality action. It can be achieved if the hospital has a service standard in the Emergency Installation. Emergency Installation Standards are set out in the Ministry of Health's Decree on Hospital Emergency Installation Standards. The research problems of this study were how the implementation of Emergency Installation standard and what factors affect the implementation. This study aimed to investigate the implementation of Hospital Emergency Installation Standards.
\end{abstract}

This study is a qualitative study with the juridical sociological approach. The juridical aspect of this study is the regulation of health minister about Hospital Emergency Installation Standards, while the sociological aspect is the implementation of the regulation by the hospital. The legal material sources of the study include primary and secondary law materials. The data were collected through interviews and literature review.

The results show that Emergency Installation Standards are regulated in Law number 44 of 2009 on Hospital. Specifically, Emergency Installation Standards have been regulated in the Minister of Health Indonesian Republic Number 856/Menkes/ SK/IX /2009 about Hospital Emergency Installation. On hospital Emergency Installation Standards. However, the reality in the field, the hospital has not implemented the regulation well, resulted in the poor quality of emergency services. Thus the patient's right to get service quality becomes neglected.

The supporting factors of the implementation of Emergency Installation Standards were the high motivation of human resources, while the obstacles factors were less strategic of the hospital location, the constraints of medical equipment financing, and the lack of attention from hospital owners.

Keywords: Implementation, Emergency Installation Standard, Hospital.

\section{PENDAHULUAN}

Rumah Sakit di Indonesia merupakan bagian dari sistem pelayanan kesehatan. Pelayanan tersebut dimulai dari Instalasi Gawat Darurat sebagai pelayanan kegawatdaruratan. Kegawatdaruratan adalah kondisi yang mengancam nyawa dan kecacatan, sehingga perlu tindakan yang cepat, tepat, efektif dan bermutu. Hal tersebut dapat dicapai jika rumah sakit mempunyai standar pelayanan di Instalasi Gawat Darurat. 
Standar Instalasi Gawat Darurat saat ini telah diatur dalam Kepmenkes RI No. 856/Menkes/SK/IX/2009 tentang Standar Instalasi Gawat Darurat (IGD) Rumah Sakit. Menurut Pasal 7 ayat (1) Undang Undang No. 44 tahun 2009 tentang Rumah Sakit "Rumah sakit harus memenuhi persyaratan administratif dan persyaratan teknis bangunan gedung pada umumnya, sesuai dengan ketentuan peraturan perundang-undangan dan persyaratan teknis bangunan Rumah Sakit, sesuai dengan fungsi, kenyamanan dan kemudahan dalam pemberian pelayanan serta perlindungan dan keselamatan bagi semua orang". Jenis - jenis pelayanan rumah sakit yang minimal wajib disediakan oleh rumah sakit meliputi: Pelayanan gawat darurat, Pelayanan rawat jalan dan Pelayanan rawat inap.'

Pada Pasal 17 Undang-Undang Rumah Sakit menegaskan bahwa "Bagi rumah sakit yang tidak dapat memenuhi persyaratan maka tidak akan diperpanjang izin operasionalnya, bahkan pemerintah dapat mencabut ijin oprasional rumah sakit tersebut".

Penelitian ini bertujuan untuk mengetahui apakah IGD RSUD Bendan Pekalongan sudah mengimplementasikan standar IGD dengan utuh, sehingga mutu pelayanan menjadi baik dan jika belum mengimplementasikan bagaimana dampak hukumnya.

\section{RUMUSAN MASALAH}

Berdasarkan uraian latar belakang diatas, maka muncul rumusan masalah adalah sebagai berikut:

1. Bagaimanakah Implementasi Kepmenkes RI No. 856/Menkes/SK/IX/2009 tentang standar Instalasi Gawat Darurat (IGD) Rumah Sakit di RSUD Bendan Kota Pekalongan?

2. Faktor-faktor apa saja yang mempengaruhi implementasi Kepmenkes RI No.856/Menkes/SK/IX/2009 tentang Standar Instalasi Gawat Darurat Rumah Sakit di RSUD Bendan Kota Pekalongan?

\section{METODE PENELITAN}

Penelitian kualitatif ini menggunakan pendekatan Yuridis Sosiologis adalah penelitian hukum yang menggunakan data sekunder sebagai data awalnya, yang kemudian dilanjutkan dengan data primer atau data lapangan. ${ }^{2}$ Aspek Yuridis dalam penelitian ini adalah peraturan menteri kesehatan Kepmenkes RI No.856/Menkes/SK/IX/2009 tentang standar Instalasi Gawat Darurat Rumah Sakit dan Aspek Sosiologis adalah pelaksanaan aturanaturan dalam kepmenkes tersebut oleh rumah sakit. Spesifikasi penelitian ini akan menggunakan deskriptif analitik yaitu penelitian yang bertujuan untuk memberikan gambaran frekuensi terjadinya gejala hukum atau frekuensi adanya hubungan hukum atau peristiwa hukum yang satu dengan yang lain secara rinci, sistematis dan menyeluruh mengenai permasalahan yang timbul dalam masyarakat dengan situasi tertentu. ${ }^{3}$ Subyek Penelitianya meliputi: Kepala Dinas Kesehatan, Direktur Rumah Sakit, Penanggung jawab IGD, Dokter dan Perawat Pelaksana dan Obyek Penelitianya yaitu IGD RSUD Bendan. Pengumpulan data dengan cara wawancara dan observasi lokasi penelitian.

\footnotetext{
${ }^{1}$ Herlambang Susatyo, 2016, Manajemen Pelayanan Kesehatan Rumah Sakit, Yogyakarta: Gosyen Publishing, hlm. 33

2 Wahyati Endang, dkk - Unika Soegijapranata, 2015, Petunjuk Penulisan Usulan Penelitian Dan Tesis. Semarang . Program Studi Magister - Unika Soegijapranata, hlm 7

3 Ibid, hlm. 8
} 


\section{PEMBAHASAN}

Implementasi adalah kegiatan untuk mendistribusikan keluaran kebijakan (to delevery policy output) yang dilakukan oleh implementer kepada kelompok sasaran (target group) sebagai upaya untuk mewujudkan tujuan kebijakan. Tujuan kebijakan akan muncul manakala policy output dapat diterima dan dimanfaatkan dengan baik oleh kelompok sasaran, sehingga dalam jangka panjang atau tertentu hasil kebijakan akan dapat diwujudkan ${ }^{4}$. Menurut Nurdin Usman dalam bukunya yang berjudul Konteks Implementasi Berbasis Kurikulum mengemukakan pendapatnya mengenai implementasi atau pelaksanaan sebagai berikut: Implementasi adalah bermuara pada aktivitas, aksi, tindakan, atau adanya mekanisme suatu sistem. Implementasi bukan sekedar aktivitas, tetapi suatu kegiatan yang terencana dan untuk mencapai tujuan kegiatan. ${ }^{5}$ Pengertian implementasi yang dikemukakan di atas, dapat dikatakan bahwa implementasi adalah bukan sekedar aktivitas, tetapi suatu kegiatan yang terencana dan dilakukan secara sungguh-sungguh berdasarkan acuan norma tertentu untuk mencapai tujuan kegiatan. Oleh karena itu implementasi tidak berdiri sendiri tetapi dipengaruhi oleh objek berikutnya. Dengan demikian maka syarat implementasi itu akan mencakup urut-urutan langkah sebagai berikut:

a) Merancang bangun (mendesain) program dengan perincian tugas, serta perumusan tujuan yang jelas.

b) Melaksanakan program dengan mendayagunakan struktur, prosedur, sumber dan metode-metode yang tepat.

c) Membangun sistem penjadwalan, monitoring dan sarana-sarana pengawasan yang tepat dan benar dapat segara dilaksanakan.

Standar Instalasi Gawat Darurat dibuat oleh Departemen Kesehatan Republik Indonesia melalui Kepmenkes RI Nomer 856/Menkes/SK/IX/2009 Tentang Standar Instalasi Gawat Darurat Rumah Sakit dimaksudkan sebagai acuan rumah sakit dalam memberikan pelayanan gawat darurat. Tujuannya yaitu untuk memberikan pelayanan kepada penderita gawat darurat dengan respon time yang cepat dan penanganan yang tepat.

Didalam standar IGD rumah sakit tersebut telah mengklasifikasikan pelayanan minimal rumah sakit berdasarkan lavel/tingkatan sebagai berikut:

1. Pelayanan Instalasi Gawat Darurat Level IV sebagai standar minimal untuk Rumah Sakit Kelas A.

2. Pelayanan Instalasi Gawat Darurat Level III sebagai standar minimal untuk Rumah Sakit Kelas B.

3. Pelayanan Instalasi Gawat Darurat Level II sebagai standar minimal untuk Rumah Sakit Kelas C.

4. Pelayanan Instalasi Gawat Darurat Level I sebagai standar minimal untuk Rumah Sakit Kelas D.

\footnotetext{
${ }^{4}$ Agus Purwanto Erwan, Op.cit., hlm. 20-21

${ }^{5}$ Abdul Wahab Solichin, 2012, Analisis Kebijakan Model-model Implementasi Kebijakan Publik, Jakarta Bumi Aksara, hlm. 235
} 
Kemudian beberapa item pokok standar yang harus dipenuhi oleh IGD rumah sakit yaitu sebagai berikut:

1. Standar Fisik Bangunan.

2. Standar Pelayanan Minimal.

3. Standar Sumber Daya Manusia.

4. Standar Sarana (Ruangan).

5. Standar Prasarana (Fasilitas Medis).

Batas waktu pencapaian target standar IGD bagi rumah sakit menurut Kepmenkes RI Nomer 856/Menkes/SK/IX/2009 yaitu paling lama lima tahun setelah dikeluarkannya SK oprasional IGD rumah sakit. Adapun sanksi administatif bagi rumah sakit yang tidak melaksanakan standar rumah sakit yaitu sesuai Pasal 27 Undang-Undang No. 44 tahun 2009 tentang Rumah Sakit bahwa "Ijin rumah sakit dapat dicabut jika sudah tidak memenuhi persyaratan atau standar".

RSUD Bendan Kota Pekalongan adalah rumah sakit kelas $C$ yang sudah terakreditasi paripurna oleh lembaga akrediatsi KARS (Komisi Akreditasi Rumah Sakit) versi 2012 pada tahun 2017. IGD RSUD Bendan termasuk dalam klasifikasi pelayanan lavel II. Dalam pelayanan lavel II IGD RSUD Bendan harus sudah mempunyai SDM, Sarana dan Prasarana yang memadai seperti yang tercantum dalam Kepmenkes RI Nomer 856/Menkes/SK/IX/2009 Tentang Standar Instalasi Gawat Darurat Rumah Sakit.

Dari hasil observasi yang peneliti lakukan IGD RSUD Bendan Kota Pekalongan belum sepenuhnya memenuhi pokok-pokok standar yang diatur dalam Kepmenkes RI Nomer 856/Menkes/SK/IX/2009 tentang Standar Instalasi Gawat Darurat. Pokok standar tersebut adalah sebagai berikut:

1) Standar Fisik Bangunan.

RSUD Bendan Kota Pekalongan memiliki muka depan yang berhadapan langsung dengan jalan satu arah yang sangat sibuk dan sering terdampak macet, sehingga akses masuk menjadi sulit karena pintu utama dan IGD berada di jalan tersebut. Hal ini tidak sesuai dengan persyaratan pada pedoman pendirian rumah sakit, yang seharusnya muka depan dan pintu masuk rumah sakit harus diletakkan di jalan yang mudah diakses secara mudah terutama oleh mobil ambulance.

Menurut undang-undang rumah sakit Pasal 7 ayat (1) menyebutkan bahwa "Rumah Sakit harus memenuhi persyaratan lokasi bangunan". Persyaratan lokasi sebagaimana dimaksud dalam Pasal 7 ayat (1) harus memenuhi ketentuan mengenai kesehatan, keselamatan lingkungan, dan tata ruang, serta sesuai dengan hasil kajian kebutuhan dan kelayakan penyelenggaraan Rumah Sakit. Selain persyaratan dalam Pasal tersebut dijelaskan dalam pedoman teknis bangunan IGD yang dikeluarkan oleh direktorat pelayanan medis Departemen Kesehatan bahwa "akses masuk ke ruang gawat darurat harus mudah dicapai terutama untuk pasien yang datang dengan menggunakan mobil ambulan". Kemudian dijelaskan pula bahwa "Pintu masuk bangunan ruang gawat darurat harus terpisah dengan pintu utama masuk rumah sakit atau dengan pintu masuk untuk pasien rawat jalan/poliklinik atau pintu masuk bangunan penunjang rumah 
sakit". 6 Sedangkan kondisi pintu IGD RSUD Bendan menjadi satu dengan pintu pengunjung dan pintu pasien ke poliklinik sehingga hal ini belum sesuai dengan standar fisik bangunan IGD.

Selain itu Fisik bangunan IGD RSUD Bendan Kota Pekalongan juga belum memenuhi beberapa item standar, dapat dilihat pada gambar 12, seharusnya peletakan IGD berada di tapak depan rumah sakit, akan tetapi IGD RSUD Bendan berada di samping bangunan. Menurut Direktur hal tersebut sudah melalui berbagai kajian tata letak, namun memang ada kendala dalam menetukan IGD karena muka depan rumah sakit berada pada jalan raya yang arusnya satu arah, sehingga tidak mungkin diletakkan dibagian muka rumah sakit, maka kami sepakat IGD diletakkan disamping bangunan. ${ }^{7}$ IGD harus mempunyai pintu masuk yang berbeda dari pintu pengunjung dan Poliklinik, yang peneliti temui bahwa pintu masuk IGD dan pengunjung masih menjadi satu, akan tetapi IGD RSUD Bendan mempunyai pintu kedua yang dapat diakes dari jalan slamet. Menurut Penanggung jawab IGD akses masuk ke IGD RSUD Bendan memang sedikit terhambat jika ada kemacetan didepan pintu IGD, jika harus lewat pintu yang berada di jalan slamet harus memutar jauh terlebih dahulu masuk gang-gang perumahan. Hal ini sudah saya usulkan untuk merubah akses masuk IGD, tapi sepertinya sulit lokasinya tidak memungkinkan. ${ }^{8}$ Menurut Direktur muka depan RSUD Bendan sekligus pintu IGD akan dilakukan penataan ulang, walaupun masih sekedar wacana tapi saya sudah ada niat untuk mengusulkan kepada wali kota. ${ }^{9}$

Didalam Kepmenkes RI Nomer 856/Menkes/SK/IX/2009 tentang Standar Instalasi Gawat Darurat disebutkan bahwa pencapaian standar dilakukan secara bertahap sesuai kemampuan rumah sakit, dan batas waktunya adalah lima tahun setelah terbitnya SK oprasional IGD. IGD RSUD Bendan sudah beroperasi sejak tahun 2009 hingga sekarang tahun 2018 berarti sudah hampir sembilan tahun beropersi. Sebenarnya hal ini sudah melewati batas waktu target pencapaian standar. Menurut Pasal 27 UU No. 44 tahun 2009 tentang Rumah Sakit bahwa "Izin rumah sakit dapat dicabut jika sudah tidak memenuhi persyaratan atau standar ". Direktur RSUD Bendan mengakui pernah mendapat teguran lisan oleh Dewan Pengawas Rumah Sakit (Dewas RS) kaitanya dengan standar IGD, "tapi itu semua saya kembalikan ke pemerintah kota selaku pemilik rumah sakit ada keinginan tidak untuk berbenah kalau saya sangat berharap segera dibenahi, mengenai sanksi administratif saya sangat paham". ${ }^{10}$

2) Standar Pelayanan Minimal.

Didalam standar pelayanan minimal sudah hampir 90\% tercapai, hanya saja angka kematian $\leq 24$ Jam masih tinggi yaitu enam per seribu, padahal angka standarnya adalah dua per seribu. ${ }^{11} \mathrm{Hal}$ ini berbeda dengan data yang disampaikan Direktur. Menurut direktur jika menggunakan standar indikator kematian $\geq 48$ Jam (Net Death Rate) angka kematianya adalah dua puluh delapan per seribu yang angka standarnya menurut Depkes 2010 adalah kurang dari empat puluh lima persen, jadi angka kematiannya

\footnotetext{
${ }^{6}$ Pedoman Teknis Bangunan IGD. Direktorat bina pelayanan penunjang medik dan sarana kesehatan Direktorat bina upaya kesehatan Kementerian kesehatan RI Tahun 2012, hlm. 3

7 Hasil wawancara dengan Direktur RSUD Bendan Kota Pekalongan

${ }^{8}$ Hasil wawancara dengan PJ IGD

9 Hasil wawancara dengan Direktur RSUD Bendan Kota Pekalongan

${ }^{10} \mathrm{lbid}$

${ }^{11}$ Wawancara dengan PJ IGD RSUD Bendan Kota Pekalongan
} 
rendah. ${ }^{12}$ Standar kematian di IGD sudah diatur dalam Kepmenkes RI Nomer 856/Menkes/SK/IX/2009 tentang Standar Instalasi Gawat Darurat yaitu menggunakan indikator angka kematian $\leq 24$ jam dan standarnya adalah dua per seribu, jadi angka kematian di IGD masih tinggi. Sedangkan NDR digunakan untuk mengukur kematian di layanan rawat inap. Menurut PJ IGD angka kematian yang tinggi tersebut tidak sematamata karena kami terlambat melayani hal ini dapat dibuktikan dengan Emergency Respon Time (ERT) yang tercatat adalah empat menit yang standarnya adalah kurang dari lima menit. "Saya berkesimpulan bahwa kematian tersebut karena penyakit fase terminal dan proses merujuk ke IGD RSUD Bendan yang terlambat”. ${ }^{13}$

3) Standar Sumber Daya Manusia.

Standar SDM di IGD RSUD Bendan Kota Pekalongan sudah 90\% tercapai, seperti sudah tersedianya empat besar dokter spesialis: Bedah, Anak, Obsgyn dan Penyakit dalam on call. Dokter umum dan perawat DIII (Pelaksana/Vokasional) sudah dibekali pelatihan penunjang seperti BTCLS, BLS dan ATCLS, hanya saja IGD RSUD Bendan belum mempunyai perawat Profesional (Ners) atau S1. Sesuai Pasal 4 undang-undang No. 38 tahun 2014 tentang Keperawatan bahwa jenis perawat dibagi menjadi "Perawat Vokasi dan Profesi". Sedangkan Perawat Profesi dibagi menjadi Ners (S1) dan Ners Spesialis (S2). Ners mempunyai peranan dan tugas penting yaitu salah satunya sebagai pengambil keputusan dalam hal asuhan keperawatan, kemudian keputusan tersebut dilaksanakan oleh perawat pelaksana (voksional). Sedangkan Ners Spesialis yaitu sebagai Konsultan. Menurut Penanggung jawab IGD memang belum ada perawat profesional di IGD, "akan tetapi saya sudah menugaskan kepada salah satu perawat DIII sebagai ketua tim yang kebetulan sekarang sedang studi lanjut di Program Studi Keperwatan (S1)". ${ }^{14}$

4) Standar Sarana (Ruangan).

Sarana yang dimiliki IGD RSUD Bendan belum sesuai dengan standar IGD menurut Kepmenkes RI Nomer 856/Menkes/SK/IX/2009. Beberapa ruangan yang belum tersedia yaitu ruangan khusus: luka bakar, HCU dan dekontaminasi. Rumah sakit kelas C dengan pelayanan IGD lavel II seharusnya memiliki ruangan-ruangan tersebut karena pasien dengan kasus-kasus khusus harus dilakukan tindakan di ruang khusus pula. Selama ini tindakan dilakukan di ruang tindakan bedah. Selain ruangan tersebut IGD RSUD Bendan sudah memiliki beberapa ruangan yang disyaratkan dalam standar IGD walaupun kurang lengkap.

Adapun ruangan yang penggunaanya tidak untuk keperuntukanya, contohnya pada saat peneliti melakukan observasi langsung di IGD ada pasien dengan indikasi tindakan resusitasi (Basic Life Support) tapi hal tersebut dilakukan di ruangan non bedah. Padahal dalam aturanya tidak diperbolehkan, alasanya Basic Life Support selain privacy tindakan tersebut perlu peralatan khusus seperti papan keras (Short Spinal Board) yang harus ada di ruangan resusitasi.

Menurut Undang-undang Rumah Sakit Pasal 29 ayat (1) butir (a) bahwa "Rumah sakit wajib melaksanakan, dan menjaga standar mutu pelayanan kesehatan di Rumah Sakit sebagai acuan dalam melayani pasien", butir (b) "menyediakan sarana dan prasarana yang layak". Maka dengan demikian IGD RSUD Bendan hendaknya segera melaksanakan

\footnotetext{
${ }^{12}$ Wawancara dengan direktur RSUD Bendan Kota Pekalongan

13 Wawancara dengan PJ IGD RSUD Bendan Kota Pekalongan

${ }^{14}$ Wawancara dengan PJ IGD RSUD Bendan Kota Pekalongan.
} 
standar IGD supaya hak-hak pasien tidak terabaikan. Didalam Pasal 29 ayat (2) menyebutkan bahwa "Pelanggaran atas kewajiban sebagaimana dimaksud pada ayat (1) dikenakan sanksi admisnistratif berupa: a. teguran; b. teguran tertulis; atau c. denda dan pencabutan izin Rumah Sakit.

Dalam pandangan Fuller sebagai ahli hukum, untuk mengetahui akan keberadaan sistem hukum, maka harus diletakkan beberapa asas yang dinamakannya principles of legality, yaitu: 1. Suatu sistem hukum harus mengandung peraturan-peraturan, dan peraturanperaturan yang telah dibuat itu harus diumumkan. 2. Tidak boleh ada peraturan yang berlaku surut. 3. Peraturan-peraturan harus disusun dalam rumusan yang bisa dimengerti dan suatu sistem tidak boleh mengandung peraturan-peraturan yang bertentangan satu sama lain, serta peraturan-peraturan tidak boleh mengandung tuntutan yang melebihi apa yang dapat dilakukan. 4. Tidak boleh ada kebiasaan untuk sering mengubah peraturan sehingga menyebabkan orang akan kehilangan orientasi dan harus ada kecocokan antara peraturan yang diundangkan dengan pelaksanaannya sehari-hari. ${ }^{15}$ Maka dengan demikian pedoman di IGD dapat dilaksanakan dengan baik harus ada pengawasan supaya tidak ada kebiasaan merubah-rubah peraturan. Pengawasan dapat dilakukan oleh ketua tim dan penanggung jawab IGD. Selain itu Dewan Pengawas Rumah Sakit selaku wakil pemilik rumah sakit/pemerintah harus berperan aktif dalam pengawasan dan pembinaan. IGD RSUD Bendan telah memiliki aturan-aturan tentang SPO penggunaan alat, SPO perawatan pasien dan alur penanganan pasien, namun semua itu belum dipasang supaya semua staf dan tenaga kesehatan yang bekerja di IGD dapat melihat setiap saat sebagai petunjuk oprasional. Seharusnya hal tersebut tidak boleh disepelekan karena itu bagian dari peraturan-peraturan yang harus dijalankan.

5) Standar Prasarana (Fasilitas Medis).

Beberapa prasarana medis di ruang-ruang IGD sudah tersedia, seperti: Ruang tindakan bedah sudah memiliki: bed dengan pengaturan manual, Bed monnitor, EKG, lampu sorot, Set medikasi, sterilisator, suction dsb. Namun demikian ada ruang atau area yang belum memiliki peralatan yaitu ruang triage. Ruangan ini sebagai garda depan dalam hal pemilahan pasien masuk ke IGD. Karena pelayanan di IGD tidak seperti di Poliklinik yaitu berdasarkan nomer antrian, melainkan berdasarkan prioritas kegawat-daruratan sehingga setiap rumah sakit harus menyedikan ruang triage yang dilengkapi dengan petugas dan peralatan yang memdai. Menurut Penanggung jawab IGD ruang tersebut sudah dikonsepkan tetapi memang belum direalisasikan, didepan pintu masuk IGD sudah saya beri tanda Triage akan tetapi saya akui itu belum berfungsi. ${ }^{16}$ Direktur RSUD Bendan membenarkan hal tersebut memang belum ada hanya baru sekedar tanda, "tanda tersebut dipasang ketika ada kegiatan akreditasi", semoga kedepan fasilitas tersebut terwujud demi mutu pelayanan kepada pasien, sehingga dengan demikian IGD RSUD Bendan dapat mengimplementasikan standar IGD secara utuh.

Menurut Denhardt "Implementasi adalah tahap tindakan atau aksi dimana semua perencanaan yang dirumusakan menjadi kebijakan yang dioprasionalkan". Sedangkan Menurut Dunn bahwa "Implementasi pada dasarnya merupakan aktifitas praktis yang dibedakan dari formulasi kebijakan yang pada dasarnya bersifat teoritis". Dalam kamus

\footnotetext{
${ }^{15}$ Rahardjo Satjipto, 2006, Ilmu Hukum, Bandung: Citra Aditya Bakti, hlm. 48-51

${ }^{16}$ Hasil wawancara dengan PJ IGD
} 
Webster dirumuskan secara pendek disebutkan sebagai berikut: "to implement (mengimplementasikan) berarti to provide the means for carrying out (menyediakan sarana untuk melaksanakan sesuatu) to give practical effect to (menimbulkan dampak atau akibat terhadap sesuatu)". ${ }^{17}$ Dari Pendapat tersebut maka implementasi kebijakan dapat dipandang sebagai suatu proses melaksanakan keputusan kebijakan. Maka dengan itu RSUD Bendan sudah seharusnya memenuhi persyaratan fisik bangunan IGD, SDM, pelayanan minimal, sarana dan prasarana. Karena dengan telah diimplementasikan suatu kebijakan baru akan dapat terlihat dampaknya bagi masyarakat, baik dampak positif maupun dampak negatif. Dampak negatif akan cenderung mengancam keselamatan pasien sehingga hak-hak pasien menjadi terabaikan. Keselamatan pasien itu sendiri dijamin dalam Pasal 4 Permenkes RI Nomor 11 tahun 2017 Tentang Keselamatan Pasien, yang standarnya meliputi:

(1) Hak pasien;

(2) Pendidikan bagi pasien dan keluarga;

(3) Keselamatan Pasien dalam kesinambungan pelayanan;

(4) Penggunaan metode peningkatan kinerja untuk melakukan evaluasi dan peningkatan Keselamatan Pasien;

(5) Peran kepemimpinan dalam meningkatkan Keselamatan Pasien;

(6) Pendidikan bagi staf tentang Keselamatan Pasien; dan,

(7) Komunikasi merupakan kunci bagi staf untuk mencapai Keselamatan Pasien.

Kemudian dalam hal control dan pengawasan terhadap penjaminan keselamatan pasien, direktur rumah sakit dan kepala IGD diperintahkan untuk melaksanakan tugas tersebut, seperti yang tertuang dalam Pasal 10 ayat (1):

Standar peran kepemimpinan dalam meningkatkan Keselamatan Pasien sebagaimana dimaksud dalam Pasal 5 ayat (4) huruf (e) merupakan kegiatan pimpinan fasilitas pelayanan kesehatan dalam:

(a) Mendorong dan menjamin implementasi Keselamatan Pasien secara terintegrasi dalam organisasi melalui penerapan tujuh langkah menuju Keselamatan Pasien;

(b) Menjamin berlangsungnya kegiatan identifikasi risiko Keselamatan Pasien dan menekan atau mengurangi insiden secara proaktif;

(c) Menumbuhkan komunikasi dan koordinasi antar unit dan individu berkaitan dengan pengambilan keputusan tentang Keselamatan Pasien;

(d) Mengalokasikan sumber daya yang adekuat untuk mengukur, mengkaji, dan meningkatkan kinerja fasilitas pelayanan kesehatan serta meningkatkan Keselamatan Pasien; dan

(e) Mengukur dan mengkaji efektifitas kontribusi setiap unsur dalam meningkatkan kinerja fasilitas pelayanan kesehatan dan Keselamatan Pasien.'

17 Denhardt, Robert B, 1995. Public Administration an Action Orientation, Wadworth Publishing Company: New York 
Dengan demikian rumah sakit berkewajiban memberikan hak-hak pasien secara utuh, supaya hak-hak pasien tersebut terjamin maka perlu pengawasan oleh kepala IGD dan direktur terhadap perawat dan dokter sebagai petugas yang memberi pelayanan kesehatan kepada pasien, karena itu merupakan bagian dari penerapan hukum di rumah sakit. Menurut Hardiati hubungan hukum antara pasien dan rumah sakit disebut "Inspaninnings Verbintanis" (iktiar sebaik-bainya menurut standar yang berlaku) yaitu merupakan hubungan hukum antara dua subjek hukum (si sakit dan si pengobat) yang melahirkan hak dan kewajiban. ${ }^{18}$

Penerapan hukum menurut Friedmen sistem hukum dibagi menjadi tiga komponen yaitu: Pertama, Struktur hukum adalah komponen struktural atau organ yang bergerak didalam suatu mekanisme, baik dalam membuat peraturan, maupun dalam menerapkan atau melaksanakan peraturan. Struktur Hukum/Pranata Hukum dalam teori Friedman hal ini disebut sebagai sistem Struktural yang menentukan bisa atau tidaknya hukum itu dilaksanakan dengan baik. ${ }^{19}$ Struktur hukum dalam kebijakan tentang standar IGD ini adalah mulai dari Kementerian Kesehatan selaku pembuat kebijakan dan RSUD Bendan Kota Pekalongan adalah sasaran target kebijakan khususnya IGD, Pelaksana kebijakannya adalah sumber daya manusia yang tercantum dalam strukture organisasi baik strukutur organisasi tingkat direktur maupun strukture organisasi tingkat Instalasi Gawat Darurat. Pengawas proses implementasi kebijakannya yaitu Dewan Pengawas Rumah Sakit (Dewas). Pembina dan sekaligus yang berwenang memberikan sanksi adalah Badan Pengawas Rumah sakit baik tingkat provinsi (BPRS Propinsi) maupun Indonesia (BPRS Indonesia). Kedua, Substansi hukum adalah produk dari struktur hukum, baik peraturan yang dibuat melalui mekanisme struktur formal atau peraturan yang lahir dari kebiasaan.

Dalam teori Friedman hal ini disebut sebagai sistem substansial yang menentukan bisa atau tidaknya hukum itu dilaksanakan. Substansi juga berarti produk yang dihasilkan oleh orang yang berada dalam sistem hukum yang mencakup keputusan yang mereka keluarkan, aturan baru yang mereka susun. Substansi juga mencakup hukum yang hidup (living law), bukan hanya aturan yang ada dalam kitab undang-undang (law books). ${ }^{20}$ Dalam hal ini substansi hukumnya adalah peraturan-peraturan dan syarat-syarat didalam Kepmenkes RI no. 856 tentang standar instalasi gawat darurat, kenapa IGD sangat perlu adannya standar, karena dengan adanya standar pelayanan dapat membantu mengurangi variasi tindakan, karena dalam pelayanan kesehatan prosedur-prosedur oprasionalnya selalu ada variasi dari setiap fasilitas kesehatan. Jika perbedaan variasi ini terlalu timpang maka bisa saja hak-hak pasien dapat terabaikan dari fasilitas kesehatan satu dengan fasilitas kesehatan lainya. Pengurangan variasi tersebut dapat melalui proses masukan, proses kerja dan keluaran (outcome) system layanan kesehatan.

RSUD Bendan masih belum mengimplementasikan beberapa pokok atau substansi standar seperti yang telah dibahas diatas. Hal ini dikarenakan terkendala masalah biaya dan masalah lahan rumah sakit yang tidak strategis. Walaupun sulit sebenarnya hal ini dapat dilakukan jika ada keseriusan dari para pihak yaitu pemerintah kota selaku pemilik

\footnotetext{
${ }^{18}$ Hardiati Hermien K, 1998. Hukum Kedokteran; Studi Tentang Hubungan Hukum Dalam Mana Dokter Sebagai Salah Satu Pihak. Bandung: Citra Aditya Bakti, hlm. 36-37

${ }^{19}$ Friedman Lawrence M., 2009, Sistem Hukum ; Perspektif Ilmu Sosial (The Legal System; A Social Science Perspective), Bandung: Nusa Media, hlm. 17.

${ }^{20} \mathrm{Ibid}$
} 
rumah sakit dapat menjembatani RSUD Bendan dengan pemerintah pusat untuk mengajukan hibah dana untuk pengadaan alat-alat kesehatan. Kemudian masalah lahan untuk membuat akses masuk dari jalan Gajah Mada langsung ke jalan slamet supaya akses masuk ke RSUD Bendan tidak sulit bagi masyarakat, direktur bisa mengusulkan sekali lagi kepada pemerintah kota untuk dapat merealisasikan akses tersebut.

Dewan Pengawas Rumah Sakit juga turut serta memberikan akses antara direktur dan pemerintah untuk berkomunikasi serta memberikan rekomendasi pembuatan akses jalan. Ketiga, Budaya Hukum: Kultur hukum menurut Friedman adalah sikap manusia terhadap hukum dan sistem hukum-kepercayaan, nilai, pemikiran, serta harapannya. Kultur hukum adalah suasana pemikiran sosial dan kekuatan sosial yang menentukan bagaimana hukum digunakan, dihindari, atau disalahgunakan. Budaya hukum erat kaitannya dengan kesadaran hukum masyarakat. Semakin tinggi kesadaran hukum masyarakat maka akan tercipta budaya hukum yang baik dan dapat merubah pola pikir masyarakat mengenai hukum selama ini. Secara sederhana, tingkat kepatuhan masyarakat terhadap hukum merupakan salah satu indikator berfungsinya hukum. Kultur hukum merupakan salah satu unsur dari sistem hukum yang mengikutsertakan masyarakat dalam hal menyerahkan sengketanya kepada institusi hukum. Dengan demikian rakyat lebih mempercayakan penyelesaian sengketanya melalui proses hukum.

Dalam hal ini sebenarnya masyarakat khususnya pasien dan keluarga yang berobat ke IGD RSUD Bendan tidak tau tentang Standar IGD, yang mereka inginkan hanya segera ditolong dan tidak terjadi cacat bahkan kematian. Hal yang dapat memotivasi pelaksanaan standar IGD yaitu adanya kewajiban rumah sakit untuk melakukan akreditasi secara berkala dalam waktu tiga tahun sekali dan adanya evaluasi setiap satu tahun sekali oleh komite akreditasi. Dalam proses visitasi yang dilakukan oleh lembaga akreditasi, yaitu akan menilai beberapa item salah satunya adalah mutu pelayanan di IGD. Dengan demikian rumah sakit akan termotivasi untuk meningkatkan mutu pelayanan, sedangkan mutu pelayanan akan tercapai jika fasilitas kesehatan memiliki standar IGD yang berlaku.

Standar IGD telah diatur dalam Kepmenkes RI No.856/Menkes/SK/IX/2009 tentang standar Instalasi Gawat Darurat Rumah Sakit. Akan tetapi tidak dipungkiri pula ada beberapa rumah sakit yang telah terakreditasi paripurna tetapi instalasi-instalasinya belum tersetandar.

Hal demikian bisa terjadi karena ada manipulasi data, panitia akreditasi menghadirkan alat dan mensetting ruangan-ruangan sementara yang di kondisikan sesuai kebutuhan akreditasi, semua itu hanya untuk keperluan akreditasi semata setelah kegiatan selesai kemudian ruangan dan peralatan dikembalikan seperti semula. Seharusnya supaya hal tersebut tidak terjadi asessor harus punya strategi observasi khusus, misal dengan datang kembali/ inspeksi mendadak ke rumah sakit bersangkutan beberapa hari setelah akreditasi, jika ada temuan-temuan yang tidak sesuai dengan kondisi observasi awal, maka komite akreditasi dapat mempertimbangkan ulang skor nilai akreditasi yang sudah didapat. Dengan demikian rumah sakit akan mempersiapkan persiapan akreditasi dengan nilai-nilai kejujuran yang hasilnya sesuai dengan realita rumah sakit saat akreditasi dilakukan.

Menurut Pure Theory of Law yang dikemukakan oleh Kelsen sebagai ahli hukum bahwa "Ada pertentangan antara alamiah dan ideal bertepatan dengan pertentangan antara 
realitas alam dan nilai, antara apa yang "ada (is) dan apa yang seharusnya (ought)."21 Para Implementator baik Direktur, Penangungjawab IGD dan SDM di RSUD Bendan seharusnya melaksanakan peaturan-peraturan dan syarat-sayarat didalam Kepmenkes no. 856 tentang Standar IGD secara utuh yang sudah dimasukan dalam pedoman IGD oleh direktur, namun yang terjadi standar tersebut belum dilaksanakan dengan baik.

Adapun beberapa faktor yang mendukung dan faktor yang menghambat implementasi yaitu:

a. Faktor Pendukung:

Faktor pendukung dalam implementasi standar IGD di RSUD Bendan yaitu motivasi dan semangat dari SDM yang tinggi untuk mencapai target standar. SDM tersbut antara lain seperti: jajaran direksi, kepala bidang, tenaga kesehatan, tenaga non kesehatan, dan para staf di RSUD Bendan. Menurut Abdul Hakim motivasi dari SDM untuk melaksanakan program juga tidak kalah penting. Motivasi sendiri adalah faktorfaktor yang ada dalam diri seseorang yang menggerakkan mengarahkan perilakunya untuk memenuhi tujuan tertentu. Proses timbulnya motivasi seseorang merupakan gabungan dari konsep kebutuhan, dorongan, tujuan dan imbalan. Proses motivasi terdiri beberapa tahapan proses sebagai berikut: pertama, munculnya suatu kebutuhan yang belum terpenuhi menyebabkan adanya ketidakseimbangan (tention) dalam diri seseorang dan berusaha menguranginya dengan berperilaku tertentu. Kedua, seseorang kemudian mencari cara-cara untuk memuaskan keinginan tersebut. Ketiga, seseorang mengarahkan perilakunya ke arah pencapaian tujuan atau prestasi dengan cara-cara yang telah dipilihnya dengan didukung oleh kemampuan, ketrampilan, maupun pengalamannya. Keempat, penilaian prestasi dilakukan oleh diri sendiri atau orang lain (atasan) tentang keberhasilannya dalam mencapai tujuan. ${ }^{22}$ Direktur RSUD Bendan sebaiknya terus memelihara motivasi dan semangat semua lapisan SDM yang ada, karena SDM merupakan salah satu penentu dari keberhasilan implementasi kebijakan.

b. Faktor Penghambat:

lokasi atau lahan untuk bangunan terletak ditempat yang kurang strategis, Pengadaan peralatan medis dan non medis yang terkendala pembiayaan yang minim, Klaim BPJS yang sering tertunda membuat oprasional tidak lancar, Wilayah kota pekalongan yang tidak begitu luas telah memiliki sembilan rumah sakit baik milik pemerintah maupun swasta, kurangnya pengawasan dan pembinaan oleh Dewan Pengawas Rumah Sakit (Dewas RS), sehingga tidak diperhatikannya kendali mutu pelayanan, pelaksanaan etika, dan pegusulan kebijakan yang lain seperti: rencana anggaran belanja, dan kurangnya informasi tentang bagaimana bentuk IGD yang sudah memenuhi standar IGD rumah sakit.

Menurut George C. Edwards III ada empat variabel yang dapat mempengaruhi kebijakan publik yaitu: Komunikasi (Communications), Sumber Daya (resources), sikap

\footnotetext{
${ }^{21}$ Kelsen Hans, 2010. Pengantar Teori Hukum. Bandung: Nusa Media.

${ }^{22}$ Hakim Abdul, Op., cit. hlm. 125-126.
} 
(dispositions atau attitudes) dan struktur birokrasi (bureucratic structure). ${ }^{23}$ Dari sisi komunikasi (Communications), antar strukture organisasi belum maksimal, sebagai contoh tidak singkronya data tentang standar pelayanan minimal antara direktur dengan kepala instalasi dan tidak satu persepsinya semua SDM yang terlibat dalam implementasi mengenai apa itu isi standar instalasi gawat darurat. Jika persepsi tentang standar IGD sudah berbeda-beda bagaimana standar IGD dapat diimplementasikan dengan baik. Kurangnya informasi tentang bentuk standar IGD menurut Kepmenkes RI Nomer 856/Menkes/SK/IX/2009 tentang Standar Instalasi Gawat Darurat mulai dari direktur, Kabid Pelayanan medis, Penanggung jawab IGD, dokter dan perawat pelaksana adalah sebagai bentuk kurangnya komunikasi antar struktural, sehingga membuat kebijakan ini tidak dapat dijalankan sebagaimana mestinya.

Kemudian komponen sumber daya (resources), ini meliputi jumlah staf, keahlian dari para pelaksana, informasi yang relevan dan cukup untuk mengimplementasikan kebijakan dan pemenuhan sumber-sumber terkait dalam pelaksanaan program, adanya kewenangan yang menjamin bahwa program dapat diarahkan kepada sebagaimana yamg diharapkan, serta adanya fasilitas-fasilitas pendukung yang dapat dipakai untuk melakukan kegiatan program seperti dana dan sarana prasarana.

SDM di IGD RSUD Bendan belum memiliki perawat dengan kualifikasi SI (Ners), sehingga dari sisi petugas pelaksana kebijakan masih kurang efektif, karena tugas dan wewenang-wewenang yang seharusnya dilakukan oleh seorang Ners tidak dapat dilakukan. Hal ini sesuai dengan teori kebijakan George C. Edwards jika "sumber daya manusia yang tidak memadahi (jumlah dan kemampuan) berakibat tidak dapat dilaksanakannya program secara sempurna karena mereka tidak bisa melakukan pengawasan dengan baik". Selanjutnya adalah sikap (dispositions atau attitudes), yaitu salah satu faktor yang mempengaruhi efektifitas implementasi kebijakan adalah sikap implementor.

Jika implemetor setuju dengan bagian-bagian isi dari kebijakan maka mereka akan melaksanakan dengan senang hati tetapi jika pandangan mereka berbeda dengan pembuat kebijakan maka proses implementasi akan mengalami banyak masalah. Ada tiga bentuk sikap/respon implementor terhadap kebijakan: kesadaran pelaksana, petunjuk/arahan pelaksana untuk merespon program kearah penerimaan atau penolakan, dan intensitas dari respon tersebut.

Implementator kebijakan di IGD RSUD Bendan yaitu mulai dari direktur, Kabid Pelayanan Medis, Penangungg jawab IGD, Kepala ruang IGD, Kepala tim dan Perawat dan Dokter Pelaksana, semua sadar dan menerima adanya kebijakan standarisasi IGD, akan tetapi semua itu belum tercapai karena ada banyak hambatan dari segi biaya dan SDM. Dan yang terakhir adalah Struktur Birokrasi (bureucratic structure), Struktur birokrasi adalah karakteristik, norma-norma, dan pola-pola hubungan yang terjadi berulang-ulang dalam badan-badan eksekutif yang mempunyai hubungan baik

${ }^{23}$ George III Edward, Implemeting Public Policy, 1980, diakses melalui http://mulyono.staff.uns.ac.id/2009/05/28/model-implementasi-kebijakan-george-edward-iii/ diunduh 10 Januari 2018 
potensial maupun nyata dengan apa yang mereka miliki dalam menjalankan kebijakan.

Bentuk strukture organisasi tentunya akan dipengaruhi oleh adanya tujuan sebuah kebijakan atau program yang diimplementasikan. Selain tujuan, kompleksitas kebijakan juga akan mempengaruhi strukture organisasi implementer. Makin komplek sebuah kebijakan atau program yang diimplementasikan maka lebih tepat jika strukturnya juga lebih komplek (complex structure) yang mampu mengakomodasi berbagai organisasi yang terlibat dalam implementasi dan juga sebaliknya jika program sederhana maka strukture juga harus sederhana (simple structure). Secara teoritis implementasi kebijakan dengan bentuk simple structure tentu akan memiliki peluang keberhasilan lebih tinggi dibanding yang menggunakan complex structure. Dalam implementasi yang menggunakan simple structure biasanya implementasi dilakukan oleh organisasi tunggal (single agency): hanya ada satu organisasi yang terlibat dalam implementasi. Sebaliknya implementasi yang menggunakan complex structure akan dilakukan oleh multiple agency: terdapat banyak organisasi sehingga implikasinya komunikasi, komando, koordinasi dan pengawasan akan lebih sulit dilakukan dibanding single agency. ${ }^{24}$

IGD RSUD Bendan menggunakan simple structure organisasi sebenarnya menurut teori ini akan lebih mudah menjalankan implementasi kebijakan, akan tetapi sekali lagi kebijakan di IGD RSUD bendan tidak berjalan maksimal karena terdapat beberapa faktor salah satunya adalah biaya. Selain hal tersebut lemahnya pengawasan dan pembinaan oleh Dewan Pengawas rumah sakit membuat kebijakan tentang standar IGD tidak berjalan. Karena dalam hal pengawasan dan pembinaan RSUD Bendan bukan wewenang Dinas Kesehatan melainkan dewan pengawas rumah sakit yang dibentuk oleh pemerintah selaku pemilik rumah sakit.

Menurut Undang-Undang Rumah sakit Pasal 56 ayat (5) bahwa: Dewan Pengawas Rumah Sakit bertugas: Menentukan arah kebijakan Rumah Sakit; Menyetujui dan mengawasi pelaksanaan rencana strategis; Menilai dan menyetujui pelaksanaan rencana anggaran; Mengawasi pelaksanaan kendali mutu dan kendali biaya; Mengawasi dan menjaga hak dan kewajiban pasien; Mengawasi dan menjaga hak dan kewajiban Rumah Sakit; dan Mengawasi kepatuhan penerapan standar, etika Rumah Sakit, etika profesi, dan peraturan perundang-undangan. Kemudian Dewan Pengawas akan melaporkan hasil pengawasan dan temuan-temuan pelanggaran terhadap lembaga yang lebih tinggi yaitu Bandan Pengawas Rumah Sakit yang berada di provinsi.

Selanjutnya Badan Pengawas Rumah Sakit akan membuat rekomendasi pembinaan terhadap rumah sakit tersebut. Jika sudah dilakukan pembinaan oleh dewan pengawas rumah sakit, kemudian rumah sakit tetap tidak melaksanakan rekomendasi tersebut, maka menurut Pasal 54 Ayat (5) berbunyi:

Dalam rangka pembinaan dan pengawasan, Pemerintah dan Pemerintah Daerah dapat mengambil tindakan administratif berupa: a. teguran; b. teguran tertulis; dan/atau c. denda dan pencabutan izin. Jika sudah dicabut izinnya akan tetapi rumah

\footnotetext{
${ }^{24}$ Agus Purwanto Erwan, 2015. Implementasi Kebijakan Publik: Konsep dan Aplikasinya di Indonesia. Yogyakarta: Gava Media, hlm. 125-135
} 
sakit tetap beropeasi maka menurut Pasal 56 bahwa "Setiap orang yang dengan sengaja menyelenggarakan Rumah Sakit tidak memiliki izin dipidana dengan pidana penjara paling lama 2 (dua) tahun dan denda paling banyak Rp. 5.000.000.000,00(lima milyar rupiah)".

Kemudian pada Pasal 63 Ayat (1) dalam hal tindak pidana sebagaimana dimaksud dalam Pasal 62 dilakukan oleh korporasi, selain pidana penjara dan denda terhadap pengurusnya, pidana yang dapat dijatuhkan terhadap korporasi berupa pidana denda dengan pemberatan 3 (tiga) kali dari pidana denda sebagaimana dimaksud dalam Pasal 62., Ayat (2) Selain pidana denda sebagaimana dimaksud pada ayat (1), korporasi dapat dijatuhi pidana tambahan berupa: a. pencabutan izin usaha; dan/atau, b. pencabutan status badan hukum.

Adapun cara mengatasi faktor-faktor penghambat tersebut dalam hal mencari solusi pencapaian standar IGD yaitu sebagai berikut:

a) Direktur RSUD Bendan segera melakukan perencanaan penataan ulang mengenai muka depan rumah sakit supaya menghadap ke jalan slamet yang mempunyai jalur dua arah dan jalan tersebut tidak terlalu sibuk. Jika memungkinkan perlu dibuka jalan masuk langsung dari jalan Gajah Mada atau jalur pantura, supaya pasien dari arah barat dapat masuk dengan akses yang mudah dan singkat tidak perlu memutar jauh menembus kemacetan jalanan kota. Kemudian Pintu IGD dan pintu masuk serta pintu keluar pengujung dipisahkan supaya arus lalulintas ke IGD tidak terganggu. Lahan parkir diletakkan ditempat yang strategis jauh dari area IGD, untuk antisipasi kesemprawutan kendaraan jika lahan parkir penuh. Pintu masuk IGD tidak perlu diberi tiket parkir manual ataupun automatis seperti pada pintu masuk pengunjung, karena dalam kondisi true emergency pasien butuh waktu tanggap darurat yang cepat (Emergency Respon Time) standarnya yaitu kurang dari lima menit.

b) Fasilitas medis di IGD sangat urgent fungsinya dan merupakan prioritas, sehingga harus segera di realisasikan. Pengadaan alat medis yang sudah masuk dalam anggaran belanja RSUD Bendan segera diteruskan ke dewan pengawas rumah sakit untuk mendapatkan rekomendasi kemudian diajukan ke pemerintah kota selaku pemilik rumah sakit. Pemerintah harus mengangarkan kebutuhan dasar RSUD Bendan dalam APBD dan APBN guna membantu BLUD mewujudkan peralatan penunjang medis di IGD RSUD Bendan. Direktur RSUD Bendan bersama pemerintah kota juga dapat melakukan lobi-lobi anggaran/hibah kepada Pemerintah Provinsi, Pemerintah Pusat, Kemenkes RI dan Kemenkeu RI untuk mendapatkan hibah alat kesehatan sebagai peralatan penunjang medis. Kerja sama dengan perusahaan alat kesehatan dengan sistem kredit, sewa, bagi hasil atau bentuk lain dalam hal pemenuhan peralatan yang sangat mahal misal seperti Ventilator dan CT-Scan.

c) Klaim BPJS yang sering tertunda mengakibatkan biaya oprasional tidak seimbang bahkan terganggu, perlu pembahasan bersama antara Direktur RSUD Bendan, Dewan Pengawas rumah sakit, Kepala BPJS, Pemerintah kota dan DPRD untuk mencari solusi-solusi dana talangan sementara sampai klaim BPJS dapat dicairkan. 
d) Peran Dewan Pengawas Rumah Sakit tidak maksimal. Menurut Pasal 55 UndangUndang Rumah Sakit "Pembinaan dan pengawasan rumah sakit secara internal dilakukan oleh Dewan Pengawas Rumah Sakit (Dewas RS) dan Pembinaan dan pengawasan secara eksternal dilakukan oleh Badan Pengawas Rumah Sakit Indonesia (BPRS). Dewas RS merupakan suatu unit nonstruktural yang bersifat independen dan bertanggung jawab kepada pemilik Rumah Sakit. Keanggotaan Dewan Pengawas Rumah Sakit terdiri dari: Dewan Pengawas Rumah Sakit terdiri dari unsur pemilik Rumah Sakit, organisasi profesi, asosiasi perumahsakitan, dan tokoh masyarakat. Dewas seharusnya dapat mengawasi setiap saat aktivitas di rumah sakit. Jika ditemukan pelanggaran etika dan perundang-undangan dapat segera dilaporkan kepada BPRS. Selain itu pengguna layanan rumah sakit dapat mudah melaporkan jika ada ketidakpuasan atau pelanggaran kepada Dewas dan atau BPRS. Selanjutnya dilakukan tindak lanjut oleh BPRS berupa pembinaan. Dengan demikian RSUD Bendan Kota Pekalongan dapat mencapai standar IGD sesuai Kepmenkes RI Nomer 856/Menkes/SK/IX/2009 tentang Standar Instalasi Gawat Darurat. Dengan memenuhi standar IGD diharapakan pelayanan menjadi berkualitas sehingga angka kematian di IGD menjadi menurun.

\section{PENUTUP \\ Kesimpulan}

Dari uraian diatas maka penulis dapat mengambil beberapa simpulan sebagai berikut:

IGD RSUD Bendan Kota pekalongan telah beroperasi selama hampir sembilan tahun dari sejak pendirian pada tahun 2009. Artinya RSUD Bendan seharusnya sudah mencapai target pencapaian standar IGD yang dalam Kepmenkes RI Nomer 856/Menkes/SK/IX/2009 tentang Standar Instalasi Gawat Darurat rumah sakit yang diberikan waktu selama lima tahun sejak dikeluarkanya SK oprasional.

Namun sampai pada tahun 2018 ini IGD RSUD Bendan belum sepenuhnya mengimplementasikan standar IGD rumah sakit.

Adapun pokok-pokok atau poin standar yang belum diimplementasikan secara penuh yaitu: Standar Fisik bangunan, Standar Pelayanan Minimal, Standar SDM, Standar Sarana dan Standar Prasarana. Menurut Pure Theory of Law bahwa apa yang "ada (is) dan apa yang seharusnya (ought) tidak bertentangan antara alamiah dan ideal. IGD RSUD Bendan belum menerapkan aturan yang seharusnya dilaksanakan dengan baik, maka menurut teori ini belum sesuai.

Mengimplementasikan peraturan dan persyaratan standar IGD merupakan bagian dari penerapan hukum di lingkungan rumah sakit supaya hak dan kewajiban terpenuhi. Menurut Hardiati hubungan hukum antara pasien dan rumah sakit disebut "Inspaninnings Verbintanis" (Iktiar sebaik-bainya menurut standar yang berlaku) yaitu merupakan hubungan hukum antara dua subjek hukum (si sakit dan si pengobat) yang melahirkan hak dan kewajiban.

Menurut Fuller untuk mengetahui akan keberadaan sistem hukum, maka harus diletakkan beberapa asas yang dinamakannya principles of legality, yaitu: Suatu sistem hukum harus mengandung peraturan-peraturan, dan peraturan-peraturan yang telah dibuat itu harus 
diumumkan.. Tidak boleh ada peraturan yang berlaku surut. Peraturan-peraturan harus disusun dalam rumusan yang bisa dimengerti dan suatu sistem tidak boleh mengandung peraturan-peraturan yang bertentangan satu sama lain, serta peraturan-peraturan tidak boleh mengandung tuntutan yang melebihi apa yang dapat dilakukan. Tidak boleh ada kebiasaan untuk sering mengubah peraturan sehingga menyebabkan orang akan kehilangan orientasi dan harus ada kecocokan antara peraturan yang diundangkan dengan pelaksanaannya sehari-hari.

Menurut Friedman sistem hukum dibagai menjadi tiga hal yaitu: 1. Strukture hukum: dalam hal ini pembuat kebijakannya adalah Kementerian Kesehatan, pelaksananya yaitu jajaran Direksi, Penangungjawab IGD, dan SDM di IGD RSUD Bendan dan sasaranya adalah Instalasi Gawat Darurat. 2. Substansi Hukum: Substansi hukumnya adalah peraturan-peraturan dan persyaratan yang ada dalam Kepmenkes RI no. 856 tentang Standar IGD rumah sakit, seperti persyaratan: Standar Pelayanan Minimal, Standar Bangunan Fisik IGD, Standar SDM, Standar Sarana dan Standar Prasarana. 3. Kulture Hukum: Masyarakat khususnya pasien dan keluaraganya yang datang ke IGD mempercayakan sepenuhnya kepada petugas baik dokter, perawat, bidan dan apoteker yang menangani pasien. Mereka tidak mengerti mengenai standar IGD yang mereka harapkan hanya segera ditangani supaya terhindar dari rasa sakit, kecacatan bahkan kematian. Sedangkan faktor pendukung dan faktor penghambat implementasi Kepmenkes RI Nomer 856/Menkes/SK/IX/2009 tentang Standar Instalasi Gawat Darurat Rumah Sakit di IGD RSUD Bendan Kota Pekalongan yaitu:

a. Faktor Pendukung:

Faktor pendukung dalam implementasi standar IGD di RSUD Bendan yaitu motivasi dan semangat dari SDM yang tinggi untuk mencapai target standar. SDM tersbut antara lain seperti: jajaran direksi, kepala bidang, tenaga kesehatan, tenaga non kesehatan, dan para staf di RSUD Bendan. Direktur RSUD Bendan sebaiknya terus memelihara motivasi dan semangat semua lapisan SDM yang ada, karena SDM merupakan salah satu penentu dari keberhasilan implementasi kebijakan.

b. Faktor Penghambat:

Beberapa faktor yang menjadi penghambat implementasi yaitu: lokasi atau lahan untuk bangunan terletak ditempat yang kurang strategis, Pengadaan peralatan medis dan non medis yang terkendala pembiayaan yang minim, Klaim BPJS yang sering tertunda membuat oprasional tidak lancar, Wilayah kota pekalongan yang tidak begitu luas telah memiliki sembilan rumah sakit baik milik pemerintah maupun swasta, kurangnya pengawasan dan pembinaan oleh Dewan Pengawas Rumah Sakit (Dewas RS).

Adapun solusinya yaitu perlu ada komunikasi rutin antar struktural khususnya dalam hal pencapaian target standar IGD dan mencari informasi tentang bentuk standar IGD yang sesuai peraturan menteri kesehatan. Langkah-langkah lain dalam pencapaian standar fasilitas medis yaitu perlu berkoordinasi dengan Dewas RS dan pemerintah untuk mencari lobi-lobi anggaran atau hibah dari pemerintah pusat untuk membantu pengadaan peralatan medis. Selain itu kantor Dewas harus berada di area rumah sakit supaya pengawasan dan pembinaan dapat maksimal. 


\section{Saran}

Mengacu pada hasil penelitian ini maka penulis menyarankan beberapa hal sebagai berikut:

1. Bagi Direktur RSUD Bendan

a. Direktur dapat mensosialisasikan kembali isi pedoman IGD, memasang alur penanganan IGD, dan Meletakan SPO di meja kerja dokter dan perawat.

b. Perlu adanya pasal tentang sanksi dalam pedoman IGD bagi yang tidak mematuhi peraturan di IGD.

c. Agar fisik bangunan IGD sesuai dengan standar yang berlaku, maka direktur RSUD Bendan segera membuat perencanaan penataan ulang tata letak IGD dan muka depan rumah sakit berhadapan dengan jalan slamet. Jika memungkinkan, membuka akses baru yaitu jalan tembus dari jalan Gajah Mada (Pantura) langsung ke jalan slamet yang panjangnya kurang-lebih 200 meter. Hal ini perlu rekomendasi dari Dewas yang nantinya diusulkan kepada Wali Kota.

d. Membuat proposal pengajuan anggaran kepada pemerintah kota untuk pembelian peralatan penunjang medis yang sangat urgent di IGD seperti; Bed monitor, AED, Ventilator mekanik, Syringe pump, Infuse pump, dan sebagainya yang standarnya tiap tempat tidur tersedia. Mengadakan lobi-lobi anggaran kepada pemerintah pusat untuk membantu pembelian peralatan medis.

e. Mencari solusi dana talangan untuk mengatasi permasalahan klaim BPJS, jika terjadi penundaan pencairan dana, supaya oprasional rumah sakit tidak terganggu.

2. Bagi Penanggung jawab IGD

Alur Kegiatan di IGD harus disesuaikan dengan standar IGD rumah sakit, yaitu dimulai dengan Triage Visual untuk menentukan False Emergency dan True Emergency. Jika petugas mengidentifikasi pasien tersebut merupakan False Emergency segera mengarahkan ke poliklinik 24 jam, Jika True Emergency diarahkan ke ruang triage dan menuju ke ruang tindakan sesuai prioritas kegawatan. RSUD Bendan saat ini tidak memiliki poliklinik umum 24 jam, maka PJ IGD segera merealisasikan fasilitas tersebut dengan cara mengusulkan kepada direktur melalui Kabid. Pelayanan Medis. Selain itu area triage harus difungsikan sebagai area pemilahan pasien bukan sebagai ruang tunggu, peralatan dan petugas harus disiapkan di area tersebut. Ruang-ruangan yang berada di IGD harus difungsikan untuk keperuntukanya, hal ini perlu pengawasan dan pembinaan oleh PJ IGD. PJ IGD mengawal pengusulan peralatan medis yang pernah diusulkan kepada direktur supaya cepat terealisasi, memastikan kembali sudah pada tahap apa saat ini. Mempelajari kembali pokok-pokok standar IGD yang harus dicapai sesuai Kepmenkes RI Nomer 856/Menkes/SK/IX/2009 tentang Standar Instalasi Gawat Darurat Rumah Sakit.

3. Bagi Pemerintah

Pemerintah Kota Pekalongan selaku pemilik RSUD Bendan, seyogyanya memperhatikan kebutuhan-kebutuhan keuangan RSUD Bendan. Pengajuan anggaran untuk keperluan yang urgent seperti pembelian peralatan penunjang medis diprioritaskan, jika hal tersebut menyerap APBD sangat banyak, pemerintah seharusnya mencarikan lobi-lobi anggaran kepada Pemerintah Provinsi, Pemerintah Pusat, Kemenkes RI dan Kemenkeu RI. Seperti yang sudah dilakukan oleh rumah sakit-rumah sakit lain. 
Supaya RSUD Bendan mudah diakses oleh masyarakat dari berbagai arah, Pemerintah Kota segera melakukan kajian tata letak muka depan rumah sakit menghadap ke jalan slamet, membuka akses baru dari jalan Gajah Mada menuju jalan slamet, supaya akses ke IGD menjadi mudah.

4. Bagi Dewan Pengawas Rumah Sakit (Dewas)

Dewas harus aktif melakukan pengawasan dan pembinaan sesuai tugasnya seperti yang tertuang dalam Pasal 56 Ayat (5) Undang-Undang Rumah Sakit.

5. Bagi Rumah Sakit-Rumah Umum Sakit khususnya Kelas $C$ Hasil penelitian ini dapat dijadikan rujukan sebagai informasi tentang standar IGD menurut Kepmenkes RI Nomer 856/Menkes/SK/IX/2009 tentang Standar Instalasi Gawat Darurat Rumah Sakit.

6. Bagi Peneliti Selanjutnya

Penelitian ini dapat dijadikan sumber informasi untuk penelitian sejenis, peneliti selanjutnya dapat meneliti rumah sakit dengan lavel standar yang lebih tinggi atau lebih rendah yaitu: lavel I untuk rumah sakit kelas D, lavel III untuk rumah sakit kelas B dan Lavel IV untuk rumah sakit kelas A.

\section{DAFTAR PUSTAKA}

Abdul Wahab Solichin, 2012, Analisis Kebijakan: Model-model Implementasi Kebijakan Publik, Jakarta: Bumi Aksara.

Agus Purwanto Erwan dan Ratih Diah S, 2015, Implementasi Kebijakan Publik: Konsep dan Aplikasinya di Indonesia. Yogyakarta: Gava Media.

Denhardt, Robert B, 1995. Public Administration an Action Orientation, Wadworth Publishing Company: New York

Friedman M. Lawrence, 2009, Sistem Hukum ; Perspektif Ilmu Sosial (The Legal System ; A Social Science Perspective), Bandung: Nusa Media.

Hakim Abdul, 2014, Dinamika Manajemen Sumber Daya Manuasia. Semarang: EF Press.

Hardiati Hermien K, 1998, Hukum Kedokteran; Studi Tentang Hubungan Hukum Dalam Mana Dokter Sebagai Salah Satu Pihak. Bandung: Citra Aditya Bakti.

Herlambang Susatyo, 2016, Manajemen Pelayanan Kesehatan Rumah Sakit, Yogyakarta: Gosyen Publishing.

Kelsen Hans, 2010. Pengantar Teori Hukum. Bandung: Nusa Media.

Wahyati Endang. dkk - Unika, 2015, Petunjuk Penulisan Usulan Penelitian Dan Tesis. Semarang: Program Studi Magister - Unika Soegijapranata.

Rahardjo Satjipto, 2006, Ilmu Hukum, Bandung: Citra Aditya Bakti.

RI, Depkes, 2012, Pedoman Teknis Bangunan Rumah Sakit Ruang Gawat Darurat. Direktorat Bina pelayanan penunjang medik dan sarana kesehatan direktorat bina upaya kesehatan kementerian kesehatan RI.

RI, Kepmenkes, 2009, No. 856/Menkes/SK/IX/2009 tentang standar Instalasi Gawat Darurat (IGD) Rumah Sakit. 
SOEPRA Jurnal Hukum Kesehatan

ISSN:2548-818X (media online) Vol. 5| No. 1 | Juni 2019

RI, Undang - Undang No. 36 tahun 2009 tentang Kesehatan.

RI, Undang -Undang No. 44 tahun 2009 tentang Rumah Sakit.

George III Edward, Implemeting Public Policy, 1980, diakses melalui http://mulyono.staff.uns.ac.id/2009/05/28/model-implementasi kebijakan-georgeedward-iii/ diunduh 10 Januari 2018. 